\title{
Rural-urban differentials in family planning practices and determinants of use among men in anambra state
}

Chigozie O. Ifeadike ${ }^{1 *}$, Precious N. Eze', Uchenna Ugwoke' and Godswill A. Nnaji²

*Correspondence: gozifeadike@yahoo.com

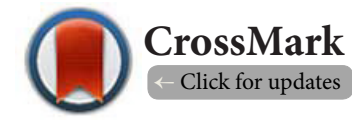

'Department of Community Medicine, Nnamdi Azikiwe University Teaching Hospital, Nnewi, Anambra State, Nigeria.

2Department of Family Medicine, Nnamdi Azikiwe University Teaching Hospital, Nnewi, Anambra State, Nigeria.

\begin{abstract}
Background: Population growth rate is rising and family planning is one way of controlling it especially when the male partners are involved.

Objectives: This study compares the family planning practices of urban and rural men in Anambra state, South-East Nigeria.

Methods: Comparative, cross sectional study design with multi-stage sampling techniques to select 194 eligible men from each of two Local Government Area, urban (Onitsha North) and rural (Ayamelum). Structured questionnaire and data was analysed with SPSS version 16 and p-value at $<0.05$.

$\underline{\text { Results: }}$ More urban respondents (41.2\%) compared with their rural counterparts (26.8\%) used a family planning method $(\mathrm{p}<0.05)$. Condom was the commonest method used $(29.9 \%$ for urban and $15 \%$ for the rural respondents) $(\mathrm{p}<0.05)$, while vasectomy was totally rejected by all respondents $\left(\mathrm{X}^{2}=12.751, \mathrm{Df}=3\right.$, $\mathrm{p}<0.05$ ). Reasons for non-use of family planning include being unaware that men use family planning $57.8 \%$ and $53.6 \%$, against my belief $17.5 \%$ and $23.2 \%$, no child yet $9.8 \%$ and $12.9 \%$; only female staff work in centres, $8.3 \%$ and $1.5 \%$, urban and rural respondents, respectively $\left(\mathrm{X}^{2}=15.001, \mathrm{Df}=5, \mathrm{p}<0.05\right)$. Reasons given for not supporting their spouses in family planning include; husband using condom, $30.4 \%$ and $20.1 \%$ being against their belief, $17.5 \%$ and $23.2 \%$; can cause cancer $10.3 \%$ and $13.9 \%$ and barrenness $4.1 \%$ and 9.3\%; wives desire for more children $2.6 \%$ and $4.1 \%$, respectively $\left(\mathrm{X}^{2}=24.14, \mathrm{Df}=6, \mathrm{p}<0.05\right)$.
\end{abstract}

Conclusion: There is a low level of family planning practice particularly among the rural respondents. Condom was the commonest method used, while vasectomy was totally rejected. Belief, religion, fear of cancer and barrenness are other reason for non-use of family planning.

Keywords: Family planning, male involvement, practices, determinants of family planning in men

\section{Introduction}

Rapid and uncontrolled population growth is a very serious problem in the developing countries of the world [1] and Nigeria like other developing countries with rapid population growth rate has a high fertility rate which is much less than the crude death rate and this is contributory to the high population growth rate [2]. According to Nigeria demographic and health survey (NDHS) 2008 , only $10 \%$ of married women were using contraceptives in Nigeria, a country with a high total fertility rate of 5.7 in 2008 [3]. It means that an average woman in Nigeria at the start of her child bearing years will give birth to 5.7 children by the end of her lifetime [3].
Family planning isthe act which allows individuals and couples to anticipate and attain their desired number of children and the spacing and timing of their births. It is achieved through use of contraceptive methods and the treatment of involuntary infertility [4]. The population of the world is now above 7 billion and developing countries contribute more than $71 \%$ [5] and it is expected to reach between 8.3 and 10.9billion by 2050 [6]. Nearly all (97\%) of the 2.3 billion projected increase will be in the less developed regions, with nearly half in Africa [7]. Sub-Saharan Africa population increases at a rate of $2.53 \%$ per annum [8], while that of Nigeria is 2.55\% [9]. Nigeria's population is above 167 million [9] and is expected to surpass 
Ifeadike et al. Epidemiology Reports 2015,

http://www.hoajonline.com/journals/pdf/2054-9911-3-5.pdf

doi: $10.7243 / 2054-9911-3-5$

the United States population in 2045 to become the third most populous country in the world, starting to rival China by the end of the century with almost 1 billion people in 2100 [10]. Nigeria still has a large unmet need for family planning and a low contraceptive prevalence rate with many having more children than planned and at a shorter than desired birth intervals [11].

Male involvement in family planning is any activity that targets males of all ages individually or as part of a sexually active couple with the aim of providing reproductive health services including information [12]. Men may be interested in family planning more than was actually perceived as reported as by some researchers [13] and were actually involved in several methods from ancient times some of which include coitus interruptus or the withdrawal method [14], periodic abstinence or rhythm method, etc [15]. It was however with the coming of the sexual revolution and advent of oral contraceptive pills in 1960 and other hormonal methods of family planning for women that led to the reduction of emphasis on menand being looked at as women's responsibility [16]. Also because of the perceived impact of men against women, sexual and reproductive health programs became designed to empower women [17]. Men were involved only when there was a need to promote diagnosis and treatment of sexually transmitted infections [18].

Because for a long time family planning has focused on women [19] with little emphasis on men, it has actually affected meeting the desired target as it was well documented that the likelihood that a woman will attempt to use a contraceptive depends a lot on the support from her partner [20]. Contraceptive use was found to actually double among couples that received husband-wife counseling compared to when women were counseled alone [21] with associated reduction in rates of pregnancy and abortion [22]. Male involvement in family planning promotes gender equality and encourages men to take responsibility for their sexual, reproductive, social and family roles [23].

The need for male partner involvement in family planning has been well stressed following the 1994 International Conference on Population and Development (ICPD) in Cairo especially because of the impact of cultural beliefs and practices on gender roles and also because the social construction of masculinity and femininity profoundly shapes sexuality, reproductive preferences, and health practices [24]. As men are usually the key decision makers in the traditional African family [25] their involvement in a very important issue like family planning cannot be overemphasized. These informed the decision to look at their practices of family planning which could be an indication of the spouse usage. Also knowing the factors that influence the practice of family planning and any effect of area of residence are important which will help program planners and providers in the course of service delivery.

This study compares the family planning practices of urban and rural men in Anambra state, South-East Nigeria.

\section{Materials and methods}

This is a descriptive, comparative, cross-sectional study conducted from January $8^{\text {th }}$ to February $7^{\text {th }} 2014$ in Onitsha North LGA (urban LGA) and Ayamelum LGA (rural LGA) both in Anambra state, Southeast of Nigeria. The state has a population of $4,177,828$ andis mainly inhabited by lgbo speaking people who are mostly Christians and most members of the population are farmers, artisans and civil servants. The study population was 388 males (194 in each LGA) aged 19-61 years of age who were sexually active and in a current sexual relationship with women aged 15-49 years regardless of their marital status but were resident in the areas of study. A multi-stage sampling technique was used to select 388 men from 388 households and the first eligible male encountered in each household was recruited for the study. Ethical permit for the study was obtained from Ethics Committee of Nnamdi Azikiwe University Teaching Hospital, Nnewi while informed consent was obtained from the respondents. Data was collected with the aid of two research assistants using self-administered questionnaire for the educated males and an interviewer-administered questionnaire for the non-educated respondents. The questionnaire was pre-tested for appropriateness and clarity on men similar in characteristics to the population studied but in different LGAs of the state. It has sections that explored the socio-demographic characteristics of the respondents, practice of family planning and also on factors influencing their decision on the practice of family planning. Data was entered and analyzed using Statistical Package for Social Sciences (SPSS) version 16. Frequencies and percentages were presented as tables. Statistical test of significance (chi square test) was done and level of significance was set at $\mathrm{P}<0.05$.

\section{Results}

The study involved 388 respondents with 194 each from urban and rural communities. Their ages range from 19-61 with a Mean \pm SD of $36.7 \pm 10.2$ and $39.9 \pm 10.6$ for urban and rural communities, respectively.

The modal age group for both urban and rural respondents was 30-39 years (Table 1 ). There was a statistically significant difference between the distribution of the age groups in the urban and rural communities $(p<0.05)$. The highest proportion of urban respondents (40.5\%) were traders, compared with their rural counterpartswho were farmers $(40.1 \%)$. There was a statistically significant difference between the distribution of occupation in both the urban and rural respondents $(p<0.05)$.

The majority of the respondents were Christians (95\%) while traditionalists and members of other religions comprised $5 \%$. Among Christians, Catholics made up of 50.5\%, (see Table 1). Also, there was a statistically significant difference $(p<0.05)$ in the distribution of religious groups between the urban and rural respondents.

The majority of the respondents in both urban and rural communities were married i.e., $61.3 \%$ and $72.2 \%$, respectively, followed by respondents who were single, i.e., $35.1 \%$ and $23.7 \%$, 
Ifeadike et al. Epidemiology Reports 2015,

http://www.hoajonline.com/journals/pdf/2054-9911-3-5.pdf

Table 1. Socio-demographic distribution of study respondents $(\mathrm{N}=388)$.

\begin{tabular}{|c|c|c|c|c|c|c|}
\hline Variable & $\begin{array}{l}\text { Urban }(n=194) \\
\text { N (\%) }\end{array}$ & $\begin{array}{l}\text { Rural (n=194) } \\
\text { N (\%) }\end{array}$ & Total & Chi-Square & Df & P-value \\
\hline \multicolumn{7}{|l|}{ Age group (years) } \\
\hline $20-29$ & $48(24.2)$ & $30(15.2)$ & 78 & 11.238 & 4 & $0.02^{\star}$ \\
\hline $30-39$ & $68(34.3)$ & $62(31.3)$ & 130 & -- & -- & -- \\
\hline $40-49$ & $55(27.8)$ & $59(29.8)$ & 114 & -- & -- & -- \\
\hline $50-59$ & $20(0.1)$ & $40(20.2)$ & 60 & -- & -- & -- \\
\hline$>60$ & $3(1.5)$ & $3(1.5)$ & 6 & -- & -- & -- \\
\hline \multicolumn{7}{|l|}{ Occupation } \\
\hline Apprentice & $16(8.2)$ & $7(3.6)$ & 23 & 135.567 & 6 & $0^{*}$ \\
\hline Civil servant & $34(17.5)$ & $11(5.7)$ & 45 & $\left(176.067^{\breve{a}}\right)$ & -- & -- \\
\hline Laborer & $15(7.8)$ & $38(19.6)$ & 53 & -- & -- & -- \\
\hline Student & $34(17.5)$ & $20(10.3)$ & 54 & -- & -- & -- \\
\hline Teacher & $17(8.8)$ & $8(4.1)$ & 25 & -- & -- & -- \\
\hline Trader & $78(40.2)$ & $29(14.9)$ & 107 & -- & -- & -- \\
\hline Farmer & $0(0)$ & $81(41.8)$ & 81 & -- & -- & -- \\
\hline \multicolumn{7}{|l|}{ Religion } \\
\hline Anglican & $52(26.8)$ & $47(24.2)$ & 99 & 38.4109 & 4 & $0^{*}$ \\
\hline Catholic & $99(51.0)$ & $94(48.5)$ & 193 & -- & -- & -- \\
\hline Other & $8(4.2)$ & $15(7.7)$ & 23 & -- & -- & -- \\
\hline Pentecostal & $34(17.5)$ & $11(5.7)$ & 45 & -- & -- & -- \\
\hline Traditional & $1(0.5)$ & $27(13.9)$ & 28 & -- & -- & -- \\
\hline \multicolumn{7}{|l|}{ Marital Status } \\
\hline Separated/Divorced & $2(1.0)$ & $0(0)$ & 2 & 8.6406 & 3 & $0.03^{* *}$ \\
\hline Married & $119(61.3)$ & $140(72.2)$ & 259 & $\left(9.641^{a}\right)$ & & $(0.02)$ \\
\hline Single & $68(35.1)$ & $46(23.7)$ & 114 & -- & -- & -- \\
\hline Widowed & $5(2.6)$ & $8(4.1)$ & 13 & -- & -- & -- \\
\hline \multicolumn{7}{|l|}{ Educational level } \\
\hline No formal & $1(0.5)$ & $38(19.6)$ & 39 & 81.378 & 3 & $0^{*}$ \\
\hline Primary & $25(12.9)$ & $52(26.8)$ & 77 & -- & -- & -- \\
\hline Secondary & $71(36.6)$ & $75(38.7)$ & 146 & -- & -- & -- \\
\hline Tertiary & $97(50.0)$ & 29(14.9) & 126 & -- & -- & -- \\
\hline
\end{tabular}

$(\breve{a})$ Correction for cells with zero ${ }^{\star} \mathrm{Chi}$-square test holds and were significant $(\mathrm{p}<0.05)$

${ }^{*}$ Yates' Chi-square $=7.085$. Yates' $p$-value $=0.069(p>0.05)$.

respectively. This difference was statistically significant $(p<0.05)$. The majority of urban respondents attained secondary and above (86.6\%) compared with their rural counterparts (53.6\%). Half of the urban respondents attained tertiary educational levels compared with only $14.9 \%$ among the rural dwellers. The difference was statistically significant $(p<0.05)$.

Table 2 shows that $41.2 \%$ ( 80 of 194) of urban and $26.8 \%$ (52 of 194) of rural respondents were using a method of family planning. However, no respondent reported use of vasectomy as family planning method. Use of condom among urban respondents was $29.9 \%$ compared with $15 \%$ by their rural counterparts. The use of withdrawal method was admitted by $11.3 \%$ urban respondents compared with $11.9 \%$ of rural respondents. Overall, $58.8 \%$ and $73.2 \%$ of the respondents for the urban and rural communities, respectively did not use any family planningmethod. The difference in the distribution of use of family planning methods between the urban and rural respondents was statistically significant $(p<.05)$.

Table 3 shows various reasons given for non-use of family planning methods. The reasons include being against their religious belief as reported by $17.5 \%$ of urban respondents and $23.2 \%$ of rural respondents while $7.2 \%$ urban and $7.7 \%$ rural respondents stated they were looking for a male child. The difference in the distribution between the two groups, 
Ifeadike et al. Epidemiology Reports 2015,

Table 2. Respondents' use of family planning methods.

\begin{tabular}{lllllll}
\hline $\begin{array}{l}\text { Family planning } \\
\text { method }\end{array}$ & $\begin{array}{l}\text { Urban }(\mathbf{n}=\mathbf{1 9 4}) \\
\mathbf{N}(\%)\end{array}$ & $\begin{array}{l}\text { Rural }(\mathbf{n}=\mathbf{1 9 4}) \\
\mathbf{N}(\mathbf{\%})\end{array}$ & Total & Chi-squared & Df & P-value \\
\hline Condom & $58(29.9)$ & $29(15)$ & 87 & 12.751 & 3 & 0.0017 \\
Withdrawal & $22(11.3)$ & $23(11.8)$ & 45 & $(12.945)$ & -- & $(0.00155)$ \\
Vasectomy & $0(0)$ & $0(0)$ & 0 & -- & -- & -- \\
Not applicable & $114(58.8)$ & $142(73.2)$ & 256 & -- & -- & -- \\
Total & 194 & 194 & 388 & -- & -- & -- \\
\hline
\end{tabular}

Table 3. Respondents' reasons for not using family planning methods.

\begin{tabular}{lllllll}
\hline Statement & $\begin{array}{l}\text { Urban }(\mathbf{n}=\mathbf{1 9 4}) \\
\mathbf{N}(\%)\end{array}$ & $\begin{array}{l}\text { Rural (n=194) } \\
\mathbf{N}(\%)\end{array}$ & Total & Chi-square & Df & P-value \\
\hline It is against my religion & $34(17.5)$ & $45(23.2)$ & 79 & 7.901 & 4 & 0.0953 \\
I am looking for a male child & $14(7.2)$ & $15(7.7)$ & 29 & $(8.105)$ & -- & $(0.08781)$ \\
I want more children & $5(2.6)$ & $10(5.2)$ & 15 & -- & -- & -- \\
I don't want & $2(1)$ & $7(3.6)$ & 9 & -- & -- & -- \\
Not applicable & $139(71.7)$ & $117(60.3)$ & 256 & -- & -- & -- \\
Total & 194 & 194 & 388 & -- & -- & -- \\
\hline
\end{tabular}

however, was not statistically significant $(P>0.05)$.

About $21.7 \%$ of urban and $25.8 \%$ of rural respondents were of the opinion that men do not go for family planning while about $36.1 \%$ of urban and $28.4 \%$ of rural respondents stated they were not aware that men go for family planning. About $8.3 \%$ of urban and $1.5 \%$ of rural respondents stated that their reason for not attending family planning clinic was because only female staff work at the health center (see Table 4). There was a statistically significant difference in the distribution of reasons for non-use of family planning methods ( $p<0.05)$.

Table 5 shows that 112 urban and 115rural respondents' wivesdid not use any family planning method and there was no statistically significant association between the use of family planning method and residence in rural or urban area $(P>0.05)$.

Table 6 shows that $10.3 \%$ of urban respondents' wives compared with $13.9 \%$ of rural respondents' wives believe that family planning methods can cause cancer in women. Similarly, $4.1 \%$ of urban respondents' wives and $9.3 \%$ of their rural counterparts believe that family planning methods can render one barren. The use of male condoms is higher among urban respondents (30.4\%) than their rural counterparts (20.1\%), while $17.5 \%$ and $23.4 \%$ of urban and rural respondents, respectively, admit that family planning methods are against their beliefs. However, one third of the urban respondents and $22.2 \%$ of their rural counterparts did not agree with the above reasons. There is a statistically significant association between the distribution of reasons for not using family planning methods and urban and rural dwelling $(p<0.05)$.

\section{Discussion}

Family planning is a veritable and indispensable means of curtailing the surge in population size in the African subcontinent as a whole and Nigeria in particular.

A high proportion of these urban and rural study populationsattained at least secondary education with many being traders, famers, professing christians and mostly married men. From the study, the level of usage of a family planning

Table 4. Reasons why respondents do not request family planning services from health centers.

\begin{tabular}{lllllll}
\hline Statement & $\begin{array}{l}\text { Urban } \\
\text { N (\%) }\end{array}$ & $\begin{array}{l}\text { Rural (n=194) } \\
\text { N (\%) }\end{array}$ & Total & Chi-square & Df & P-value \\
\hline Men do not go for family planning & $42(21.7)$ & $49(25.3)$ & 91 & 14.116 & 5 & 0.01489 \\
I am not aware that men do family planning & $70(36.1)$ & $55(28.3)$ & 125 & $(15.001)$ & -- & $(0.01036)$ \\
No child/not yet & $19(9.8)$ & $25(12.9)$ & 44 & -- & -- & -- \\
It is against my belief & $34(17.5)$ & $45(23.2)$ & 79 & -- & -- & -- \\
Only female staff work at the health centre & $16(8.3)$ & $3(1.5)$ & 19 & -- & -- & -- \\
Not applicable & $13(6.7)$ & $17(8.8)$ & 30 & -- & -- & -- \\
Total & 194 & 194 & 388 & -- & -- & -- \\
\hline
\end{tabular}


Ifeadike et al. Epidemiology Reports 2015,

http://www.hoajonline.com/journals/pdf/2054-9911-3-5.pdf

Table 5. Respondents' wives/partners use of any family planning method.

\begin{tabular}{lllllll}
\hline $\begin{array}{l}\text { Family planning method } \\
\text { used by wives }\end{array}$ & $\begin{array}{l}\text { Urban }(\mathbf{n}=\mathbf{1 9 4}) \\
\mathbf{N}(\%)\end{array}$ & $\begin{array}{l}\text { Rural }(\mathbf{n = 1 9 4 )} \\
\mathbf{N}(\%)\end{array}$ & Total & Chi-square & Df & P-value \\
\hline Natural method & $35(18)$ & $41(21.1)$ & 76 & 4.374 & 5 & 0.49687 \\
Coil & $14(7.2)$ & $13(6.7)$ & 27 & -- & -- & -- \\
Implant & $6(3.1)$ & $1(0.5)$ & 7 & -- & -- & -- \\
Injectable & $17(8.8)$ & $16(8.3)$ & 33 & -- & -- & -- \\
Pills & $10(5.2)$ & $8(4.1)$ & 18 & -- & -- & -- \\
None & $112(57.7)$ & $115(59.3)$ & 227 & -- & -- & -- \\
Total & 194 & 194 & 388 & -- & -- & \\
\hline
\end{tabular}

Table 6. Reasons respondents' wives/partners do not use any family planning method as given by the men.

\begin{tabular}{lllllll}
\hline Statement & $\begin{array}{l}\text { Urban }(\mathbf{n}=\mathbf{1 9 4}) \\
\mathbf{N}(\%)\end{array}$ & $\begin{array}{l}\text { Rural (n=194) } \\
\mathbf{N}(\%)\end{array}$ & Total & Chi-square & DF & P-value \\
\hline She will go after men & $1(0.5)$ & $8(4.1)$ & 9 & 23.12 & 6 & $0.002^{*}$ \\
It will cause cancer for her & $20(10.3)$ & $27(13.9)$ & 47 & $(24.14)$ & -- & $(0.001)$ \\
It will make her barren & $8(4.1)$ & $18(9.3)$ & 26 & -- & -- & -- \\
Wife wants more children & $5(2.6)$ & $8(4.1)$ & 13 & -- & -- & -- \\
No children yet & $2(1.0)$ & $6(3.1)$ & 8 & -- & -- & -- \\
Husband uses condom & $59(30.4)$ & $39(20.1)$ & 98 & -- & -- & -- \\
It is against my belief & $34(17.5)$ & $45(23.2)$ & 79 & -- & -- & -- \\
Not applicable & $65(33.5)$ & $43(22.2)$ & 108 & -- & -- & -- \\
Total & 194 & 194 & 388 & -- & -- & -- \\
\hline
\end{tabular}

method doesn't seem encouraging as only $41.2 \%$ of urban respondents and $26.8 \%$ of rural respondents were using family planning methods. The rural communities were actually using fewerfamily planning services compared to their urban counterpart.

The condom ( $29.9 \%$ urban and $15 \%$ rural) was the most common family planning method being used. This agrees with the findings of Orji et al., [26] and NDHS [3], which also showed that the male condom was the most common modern family planning method used by married men. The rate of condom use is still very low and implies a large unmet need in the area of condom use.

This study found a total rejection of vasectomy by all the respondents. This could be because the cultural norms and beliefs of the society do not favor male sterilization. People believe that a man cannot lose his fertility which is equivalent to masculinity [24]. They believe that vasectomy could affect their image within the family and community.

Overall, a large proportion $58.8 \%$ and $73.2 \%$ of the urban and rural respondents, respectively do not use any method of family planning. This is consistent with findings by Lawoyin et alin a study carried out in south west Nigeria [27]. There appears so much gap in the use of family planning methods, which calls for more action considering the high population growth rate in the country.

The place of religion cannot be over emphasized as it is a major determinant to the use of family planning methods. This was found to be one of the major determinants influencing the decision of men or their spouse to use family planning services. This finding is in agreement with that of lliyazu et al in similar studies in northern Nigeria [28]. The implication of this finding is that family planning is not an exclusive preserve of health workers but an area needing the involvement of religious leadersand others with the aim of reaching acceptable compromise on various issues in family planning. There is need to consider cultural factors, religious and other opinions in the communities involved in order to have acceptable and effective family planning approach.

The study found other reasons given by respondents for not using family planning such asdesire for a male child, family planning methods as causing cancer or barrenness, etc. These findings show that the behavioural aspect of family planning acceptance is complex and requires in-depth studies to unravel.

The study found that the absence of a male provider in family planning centres is repulsive to some men and tends to portray the idea that family planning is a woman's affair. This underlies the need to make family planning service delivery friendlier and attractive to both genders.

Comparatively, more of those that live in urban areas make use of a family planning methods than their rural counterparts. There is however, no statistically significant difference between the two study groups. The reasons for not using 
Ifeadike et al. Epidemiology Reports 2015,

http://www.hoajonline.com/journals/pdf/2054-9911-3-5.pdf

doi: $10.7243 / 2054-9911-3-5$

family planning methods by respondents' wives include being against belief, fear of cancer and barrenness and desire for more children. These findings appear more in the rural study population were the level of education is lower and religious belief higher.

\section{Recommendation}

Men should be involved in the decision for family planning methods with their spouses.

There is need for well-planned male-targeted programs and involving male providers at the family planning centres. Religious leaders need to be involvedin the debate on acceptance of family planning by their followers.

There is need to address the misconceptions about family planning and to conduct further studies on the behavioural aspect of family planning practice.

\section{Conclusion}

Overall, a large proportion of both the urban and rural respondents do not use any family planning method. Consequently, the level of usage of family planning methods is low among the urban and rural respondents. The rural communities used less family planning services compared with their urban counterpart. The condom was the most commonly used family planning method in both groups with a greater proportion among the urban than in the rural respondents. This study found a total rejection of vasectomy by all the respondents both in the urban and rural communities. Belief, religion and fear of cancer and barrenness were other reasons for non-use of family planning methods.

\section{Competing interests}

The authors declare that they have no competing interests.

Authors' contributions

\begin{tabular}{|l|c|c|c|c|}
\hline Authors' contributions & ICO & ENP & UUM & NGA \\
\hline Research concept and design & $\checkmark$ & $\checkmark$ & $\checkmark$ & -- \\
\hline Collection and/or assembly of data & $\checkmark$ & $\checkmark$ & $\checkmark$ & -- \\
\hline Data analysis and interpretation & $\checkmark$ & $\checkmark$ & $\checkmark$ & $\checkmark$ \\
\hline Writing the article & $\checkmark$ & $\checkmark$ & $\checkmark$ & $\checkmark$ \\
\hline Critical revision of the article & -- & -- & -- & $\checkmark$ \\
\hline Final approval of article & $\checkmark$ & -- & -- & $\checkmark$ \\
\hline Statistical analysis & $\checkmark$ & $\checkmark$ & $\checkmark$ & $\checkmark$ \\
\hline
\end{tabular}

\section{Acknowledgement}

We acknowledge the staff of Community Medicine

Department for their efforts in the preparation of this study.

Publication history

Editor: Randall E. Harris, The Ohio State University, USA.

Received: 22-Oct-2015 Final Revised: 19-Nov-2015

Accepted: 10-Dec-2015 Published: 18-Dec-2015

\section{References}

1. Mistik S, Nacar M, Mazicioglu M and Cetinkaya F. Married men's opinions and involvement regarding family planning in rural areas. Contraception. 2003; 67:133-. I Article I PubMed
2. Isiugo-Abanihe UC. Reproductive motivation and family-size preferences among Nigerian men. Stud Fam Plann. 1994; 25:149-61. | Article | PubMed

3. National Population Commission (NPC) and ICF Macro. Nigeria Demographic and Health Survey 2008, National Population Commission and ICF Macro, Abuja, Nigeria. 2009. I Pdf

4. World Health Organization. Health topics: family planning. WHO. 2013. | Website

5. United State Census Bureau. USCB world POP clock projection. 2012. I Website

6. UN News Center. World population projected to reach 9.6 billion by 2050. UN report. 2013. | Website

7. World Population to surpass 7 billion in 2011. Explosive population growth means challenges for developing nations. Harvard school of Public Health. 2011. I Website

8. Trading Economics. Population growth (annual \%) in sub-Saharan Africa. World Bank indicators. 2012. I Website

9. Advanced family planning 2011. AfriComNet. 2013. | Website

10. World Population Clock: 7 Billion people (2013)-worldometers. | Website

11. Kofoworola $\mathrm{AO}$ and Bose El. Promoting male participation in family planning in rural Nigeria: A community-based intervention. International conference on family planning. 2011. | Article

12. Danforth $N$ and Green $C P$. Involving men in reproductive health: a review of USAID-funded activities. POPTECH Report. Population Technical Assistance Project, Arlington, VA. 1997. I Pdf

13. Clark J, Yount KM and Rochat R. Men's involvement in family planning in rural Bangladesh. J Biosoc Sci. 2008; 40:815-40. | Article I PubMed

14. Cummings DE and Bremner WJ. Prospects for new hormonal male contraceptives. Endocrinol Metab Clin North Am. 1994; 23:893-922. | Article | PubMed

15. Caldwell J, Gaminiratne KH, Caldwell P, de Silva S, Caldwell B, Weeraratne $\mathrm{N}$ and Silva $\mathrm{P}$. The role of traditional fertility regulation in Sri Lanka. Stud Fam Plann. 1987; 18:1-21. | Article | PubMed

16. Okwor EU and Olaseha IO. Married men's perception about spousal use of modern contraceptives: a qualitative study in Ibadan northwest local government area, Southwest Nigeria. Int Q Community Health Educ. 2009; 30:223-38. | Article | PubMed

17. Sternberg $P$ and Hubley J. Evaluating men's involvement as a strategy in sexual and reproductive health promotion. Health Promot Int. 2004; 19:389-96. | Article | PubMed

18. Mbizvo MT and Bassett MT. Reproductive health and AIDS prevention in sub-Saharan Africa: the case for increased male participation. Health Policy Plan. 1996; 11:84-92. I Article I PubMed

19. Greene ME and Biddlecom AE. Absent and problematic men: Demographic accounts of male reproductive roles. Population and Development Review. 2000; 26:81-115. | Article

20. Santelli JS, Kouzis AC, Hoover DR, Polacsek M, Burwell LG and Celentano DD. Stage of behavior change for condom use: the influence of partner type, relationship and pregnancy factors. Fam Plann Perspect. 1996; 28:101-7. | Article | PubMed

21. Terefe A and Larson CP. Modern contraception use in Ethiopia: does involving husbands make a difference? Am J Public Health. 1993; 83:1567-71. | PubMed Abstract | PubMed Full Text

22. Wang CC, Vittinghoff E, Hua LS, Yun WH and Rong ZM. Reducing pregnancy and induced abortion rates in China: family planning with husband participation. Am J Public Health. 1998; 88:646-8. I PubMed Abstract | PubMed Full Text

23. Bernstein S and Hansen CJ. Public choices, private decisions: Sexual and reproductive health and the millennium development goals. UN Millennium Project Report: United Nations Development Programme. 2006. | Website

24. United Nations. Report of the International Conference on Population and Development. Cairo. New York. 1994; 30. I Website

25. Oyediran KA, Ishola GP and Feyisetan BJ. Factors affecting ever-married 
Ifeadike et al. Epidemiology Reports 2015,

http://www.hoajonline.com/journals/pdf/2054-9911-3-5.pdf

men's contraceptive knowledge and use in Nigeria. J Biosoc Sci. 2002; 34:497-510. | Article | PubMed

26. Orji EO, Adegbenro CA and Olalekan AW. Prevalence of sexual activity and family-planning use among undergraduates in Southwest Nigeria. Eur J Contracept Reprod Health Care. 2005; 10:255-60. | Article | PubMed

27. Lawoyin TO, Osinowo H, Babatunde M, Bajomo TG, Betiku AO, Biakolo, Busari KT and Fehintola A. Family planning in rural Nigeria: a study among men. Afr J Med Med Sci. 2002; 31:159-62. | Article | PubMed

28. lliyazu Z, Mandara MU and Mande AT. Community leaders' perception of reproductive health issues and programmes in northern Nigeria. Trop $J$ Gynaecol. 2004; 2:83-87.

\section{Citation:}

Ifeadike CO, Eze PN, Ugwoke U and Nnaji GA.

Rural-urban differentials in family planning practices and determinants of use among men in anambra state. Epidemiol Rep. 2015; 3:5.

http://dx.doi.org/10.7243/2054-9911-3-5 